\title{
NEUROGENESIS IN APLYSIA CALIFORNICA RESEMBLES NERVOUS SYSTEM FORMATION IN VERTEBRATES ${ }^{1}$
}

\author{
MICHELE H. JACOB ${ }^{2}$ \\ Center for Neurobiology and Behavior, Department of Psychiatry, Columbia University, College of Physicians and Surgeons, \\ New York, New York 10032
}

Received July 12, 1983; Revised December 12, 1983; Accepted December 13, 1983

\begin{abstract}
The pattern of neurogenesis of the central nervous system of Aplysia californica was investigated by $\left[{ }^{3} \mathrm{H}\right]$ thymidine autoradiography. Large numbers of animals at a series of early developmental stages were labeled with $\left[{ }^{3} \mathrm{H}\right]$ thymidine for 24 or $48 \mathrm{hr}$ and were subsequently sampled at specific intervals throughout the life cycle. I found that proliferative zones, consisting of columnar and placodal ectodermal cells, are established in regions of the body wall adjacent to underlying mesodermal cells. Mitosis in the proliferative zones generates a population of cells which leave the surface and migrate inward to join the nearby forming ganglia. Tracing specific $\left[{ }^{3} \mathrm{H}\right]$ thymidinelabeled cells from the body wall to a particular ganglion and within the ganglion over time suggests that the final genomic replication of the neuronal precursors occurs before the cells join the ganglion while glial cell precursors and differentiating glial cells continue to divide within the ganglion for some time. Ultrastructural examination of the morphological features of the few mitosing cells observed within the Aplysia central nervous system supports this interpretation. The pattern of neurogenesis in the Aplysia central nervous system resembles the proliferation of cells in the neural tube and the migration of neural crest and ectodermal placode cells in the vertebrate nervous system but differs from the pattern described for other invertebrates.
\end{abstract}

The ectodermal layer of both vertebrates and invertebrates is the source of the population of precursor cells which ultimately divide and differentiate into the neurons and glial cells of the central (CNS) and peripheral (PNS) nervous system. A specific pattern of cell proliferation, migration, differentiation, and death characterizes the formation of a particular neural structure. The marine gastropod mollusc, Aplysia californica, is a useful animal for investigation of the pattern of neurogenesis of a simple, well characterized, unsegmented CNS which is composed of a relatively small number of cells (for a review see Kandel, 1976, 1979). The ability to raise Aplysia in the laboratory (Kriegstein et al., 1974) has now made it possible to trace the sequence of CNS

\footnotetext{
${ }^{1}$ This work was supported by grants from the New York State Health Research Council (1798), the Neurobehavioral Science Research Training Program (MH 15174-02), and the Klingenstein Foundation. I thank Drs. Eric Kandel and Sam Schacher for providing guidance and laboratory facilitics, Tom Capo and Susan Perritt for rearing the animals in the mariculture facility in Woods Hole, MA, Alfredo Franco, Jr. for skilled technical assistance with the preparation of the figures, and Drs. Eric Kandel, William Harris, Janet Lamborghini, John Kuwada, and Joel Glover for reviewing this manuscript.

${ }^{2}$ Present address: Department of Biology, B-022, University of California, San Diego, La Jolla, CA 92093.
}

formation from early embryonic stages by the use of $\left[{ }^{3} \mathrm{H}\right]$ thymidine labeling. Thymidine is a specific precursor of chromosomal DNA which is incorporated into the cell nucleus when DNA replication occurs (Cleaver, 1967; Sidman, 1970). $\left[{ }^{3} \mathrm{H}\right]$ Thymidine labeling of an egg mass from a single adult animal establishes a large experimental population labeled at a specific embryonic stage for sampling throughout the life cycle. Additionally, the hemolymph of the animals is essentially iso-osmotic with sea water during the embryonic and veliger stages of early development (Saunders and Poole, 1910; Kriegstein et al., 1974; Kriegstein, 1977a), enabling easy access of radioactive thymidine to internal regions without disturbance to the animals or their environment.

The development of A. californica occurs in four major phases (Saunders and Poole, 1910; Kriegstein et al., 1974; Kriegstein, 1977a), which are summarized here to provide a time scale for the thymidine labeling experiments. The embryonic phase extends from the fertilized egg to hatching, requires 10 to 12 days, and includes: the early cleavage stages (day 1 following fertilization), blastula (day 2 ), gastrula (day 3), segmentation cavity (day 4), trochophore, a ciliated embryo that has the beginning of a celomic cavity (day 5), late trochophore (day 6), veliger (days 7 and 8), followed by hatching from the egg mass 
at days 9 to 12 as a free-swimming planktonic stage 1 veliger. The veliger or larval phase undergoes a series of developmental changes over 32 to 34 days that have been divided into six stages which terminate with the metamorphosis of the animal into a crawling, benthic form. Metamorphosis occurs over a period of 2 to 3 days and is followed by the final phase of development, the postmetamorphic or juvenile stage, which results in a reproductively mature adult within approximately 80 to 90 days.

Earlier studies of the development of the Aplysia CNS at the light and electron microscopic levels have shown that the anlage of the cerebral, pedal, and abdominal ganglia are already present in a stage 1 hatched veliger, approximately 10 days following egg laying (Kriegstein, 1977a, b; Schacher et al., 1979a). Based upon this information and the finding in other preparations that specific neuronal populations originate during gastrulation (Vargas-Lizardi and Lyser, 1974; Kimmel et al., 1978; Lamborghini, 1980), I have extended the study of neurogenesis in Aplysia from the early embryonic stage of gastrula to postmetamorphic stages of young juvenile development.

\section{Materials and Methods}

$\left[{ }^{3} H\right]$ Thymidine labeling. Egg masses laid by adult $A$. californica were maintained in fresh aerated sea water at $15^{\circ} \mathrm{C}$ at the mariculture facility in Woods Hole, MA. Animals at various embryonic and veliger stages of development ranging from gastrula to spotted stage 6 , the last larval stage, were labeled with $\left[\right.$ methyl $\left.-{ }^{3} \mathrm{H}\right]$ thymidine (specific activity $20.0 \mathrm{Ci} / \mathrm{mmol}$, New England Nuclear Corp., Boston, MA). At the embryonic stages, lengths of egy mass segments were selected for the labeling of approximately 30,000 eggs (Kandel and Capo, 1979)/ quart of radioactive sea water. At the larval stages, 8,000 veligers were labeled/gallon of radioactive sea water. The sea water contained $1.25 \times 10^{-8} \mathrm{M}\left[{ }^{3} \mathrm{H}\right]$ thymidine and $10^{-5} \mathrm{M}$ cold cytidine to prevent DNA synthesis inhibition (Cleaver, 1967). Animals were labeled for 24 or $48 \mathrm{hr}$ and much of the $\left[{ }^{3} \mathrm{H}\right]$ thymidine remained in the sea water bath throughout this period. Animals were then rinsed for $24 \mathrm{hr}$ in several changes of fresh sea water. In the first few experiments the sea water washes were monitored by liquid scintillation counting to establish the sufficiency of the rinsing procedure for the removal of unincorporated $\left[{ }^{3} \mathrm{H}\right]$ thymidine. The labeled embryos and veligers were subsequently maintained in gallon jars of fresh sea water at the mariculture facility in Woods Hole. Samples were removed for fixation and autoradiographic processing at predominantly $2-, 4-$, and 7 -day intervals. At the appropriate stage the remaining veligers were induced to metamorphose by addition of the triggering seaweed, Laurencia pacifica, to the sea water (Kriegstein et al., 1974). Immediately after metamorphosis samples were removed for processing at 1 - to 2 -week intervals. Late juvenile and adult developmental stages were sampled at monthly intervals.

Sample preparation. Samples of $\left[{ }^{3} \mathrm{H}\right]$ thymidine-labeled animals were narcotized at the embryonic and veliger stages by exposure to increasing concentrations of propylene phenoxytol (Leibowitz, 1976) and at the juvenile stage by immersion in isotonic $\mathrm{MgCl}$ to prevent muscular contractions in response to the fixative. The animals were fixed for $1 \mathrm{hr}$ in cold $6 \%$ glutaraldehyde in $0.2 \mathrm{M} \mathrm{s}-$ collidine buffer, $\mathrm{pH} 7.5$, containing $0.7 \mathrm{M}$ sucrose and 0.7 $\mathrm{mM} \mathrm{CaCl}_{2}$ (Thompson et al, 1976). Animals were rinsed in several changes of cold $0.2 \mathrm{M}$ s-collidine buffer for 1 $\mathrm{hr}$ and postfixed for $1 \mathrm{hr}$ in $1 \%$ osmium tetroxide in 0.1 M Sorensen's phosphate buffer, pH 7.4, containing $0.7 \mathrm{M}$ sucrose. 'I'he larval shells were decalcified for $1 \mathrm{hr}$ by immersion in $10 \%$ EDTA, pH 7.4. The tissue was dehydrated in a graded series of ethanol and embedded in Epon with animals oriented in the rostral to caudal direction.

Light and electron microscope autoradiography. Two to three animals at each stage sampled were cut serially into 2- to 4- $\mu \mathrm{m}$ thick sections for light microscope autoradiography (LM-ARG). The sections were mounted on cleaned glass slides and dipped in Ilford L4 emulsion (Polysciences) diluted 1:2 with warm Millipore-filtered distilled water. Coated slides were stored in the darkroom at room temperature for 2 months. LM-ARG slides were then developed for $4 \mathrm{~min}$ at $20^{\circ} \mathrm{C}$ in Kodak D-19 and fixed for 4 min in Kodak Rapid Fix. Sections were stained with $1 \%$ toluidine blue and viewed by brightfield microscopy.

For electron microscope (EM) ARG, serial thin sections (80 to $100 \mathrm{~nm}$ ) of particular ganglia or of reembedded LM-ARG thick sections were mounted on Formvar-coated slot hole copper grids and covered with Ilford L4 emulsion diluted 1:4 by looping. Following storage for several months, the grids were developed for $4 \mathrm{~min}$ at $20^{\circ} \mathrm{C}$ in fresh Kodak Microdol-X, fixed for 3 to 4 min in Kodak Rapid Fix, rinsed, stained with uranyl acetate and lead citrate, and examined in a Philips EM 301 electron microscope.

\section{Results}

Identification of $\left[{ }^{3} \mathrm{H}\right]$ thymidine-labeled ganglion cells. Tracing the migration of individual $\left[{ }^{3} \mathrm{H}\right]$ thymidine-labeled cells from the ectodermal layer of the body wall to specific ganglia has lead to the proposal of a model of neurogenesis in A. californica (Fig. 1). According to this model, cells that are generated in proliferative zones of the body wall leave the surface and migrate to nearby ganglia. Within the various ganglia, differentiation of the newly arriving immature cells occurs over time.

Not all $\left[{ }^{3} \mathrm{H}\right]$ thymidine-labeled migrating cells from the body wall take up positions in the nervous system. Only labeled cells within the ganglia are traced throughout development. In addition, not all labeled cells within the ganglia are neurons. Neurons do not divide, and thus $\left[{ }^{3} \mathrm{H}\right]$ thymidine incorporated during their final genomic replication is permanently present (Cleaver, 1967; Sidman, 1970). In general, non-neuronal cells continue to divide for some time, diluting the intensity of their radioactivity and enabling the distinction of neurons from non-neuronal cells by their high degree of labeling. Using this and morphological characteristics to identify neurons and non-neuronal cells, the pattern of neurogenesis in A. californica is described in detail.

Source of ganglion cells. Beginning in the early egg mass stage of gastrula and continuing through to post- 

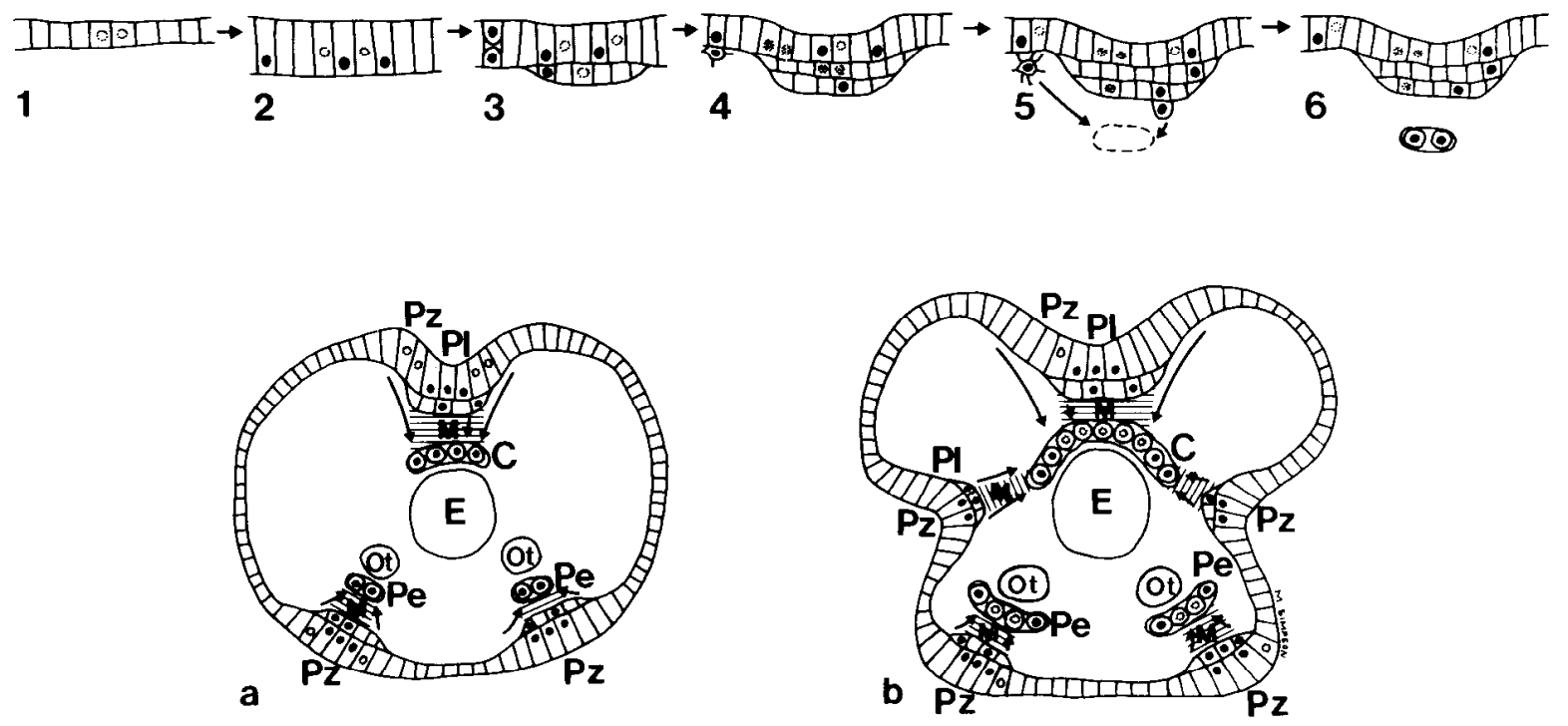

\section{1}

Figure 1. Schematic representation of neurogenesis in Aplysia californica. Proliferative zones of the body wall are the source of ganglion cells of the Aplysia CNS. The sequence of cell proliferation in the proliferative zones and the migration to the nearby ganglia are illustrated schematically in magnified views of the body wall as it changes over time during neurogenesis $(1 \rightarrow 6)$ and in cross-sections of two developmental stages of the whole animal ( $a$, gastrula to segmentation cavity stage embryo, 1 week following labeling with $\left[{ }^{3} \mathrm{H}\right]$ thymidine; $b$, trochophore stage embryo, 1 week following labeling. The top of each figure is dorsal, and the bottom is ventral). Proliferative zones $(P z)$ are established in regions of the body wall which are adjacent to underlying mesodermal cells $(M)$ (see $a$ and $b$ for orientation in cross-sections of the whole animal). The proliferative zones contain ectodermal cells which have elongated from a flat or cuboidal state to a columnar shape $(1 \rightarrow 2)$. Multilayered placodes $(P l)$ form in a central portion of each proliferative zone $(2 \rightarrow 4)$. Mitosis of the columnar and placodal cells of the proliferative zones in the presence of $\left[{ }^{3} \mathrm{H}\right]$ thymidine leads to the production of heavily labeled cells $\left(\boldsymbol{O},\left[{ }^{3} \mathrm{H}\right]\right.$ thymidine-labeled cell nucleus as compared to $\bigcirc$, unlabeled cell nucleus). The region has a pseudostratified appearance with nuclei seeming to migrate to the basal area of the cell during the cell cycle. Some labeled cells leave the surface and migrate inward along the paths indicated by the arrows to join the nearby forming ganglia $(5 \rightarrow 6, a$ and $b)$. Each ganglion $(C$, cerebral; $P e$, pedal indicated here) is formed by cells generated in a unique adjacent proliferative zone. Other internal structures indicated include the esophagus $(E)$ and the otocysts $(O t)$.

metamorphic development, ectodermal cells in specific regions of the body wall are elongated from their normally flat to cuboidal state to a columnar shape. This occurs in regions of the body wall adjacent to underlying mesodermal cells which differentiate into muscle (Figs. 1 and 2). The columnar ectodermal cells undergo frequent mitoses, forming proliferative zones. The region has a pseudostratified appearance with nuclei seeming to migrate to the basal area of the cell during the cell cycle (Figs. 1 and 2). A multilayered placode is present in a central portion of each proliferative zone (Figs. 1 and $2 b$ ).

The columnar and placodal cells were shown to be the source of ganglion cells by following $\left[{ }^{3} \mathrm{H}\right]$ thymidine-labeled cells from the body wall to the forming ganglia. The proliferative zones are heavily labeled following exposure of embryonic stages starting with gastrula to $\left[{ }^{3} \mathrm{H}\right]$ thymidine (Fig. 3). The first few generations of progeny produced in the labeled proliferative zones are heavily to moderately labeled. As the body wall cells continue to divide, the intensity of their radioactivity is diluted and becomes low to undetectable within approximately 2 to 3 weeks following $\left[{ }^{3} \mathrm{H}\right]$ thymidine exposure. Intensely labeled progeny which do not divide many times are easily distinguished, and their fates can be determined.
Following individual cells into the ganglia. Mitosis in the proliferative zones gives rise to body wall cells and to a population of cells which can be followed in animals at successive developmental stages as they detach from the surface and migrate a short distance to nearby regions of ganglion formation (Figs. 1 and 3). Two modes of migration are used: a streaming of cells inward from the surface and a crawling of cells along a particular path (Fig. 4). Cells which migrate by streaming extend out from the body wall in a column or stream into the nearby region of the forming ganglion. Their surface is rounded and smooth. Cells which migrate by crawling have numerous thin processes or pseudopodia which extend out from their surface and appear to contact the inner surface of body wall cells, muscle extending in from the body wall, or strands of extracellular matrix present between the body wall and the muscle. Migrating cells stream or crawl as individuals or in small clusters.

In a few cases it is possible to follow specific heavily labeled cells in animals at a series of successive developmental stages as they migrate and become part of a ganglion. The cells can be traced because they remain heavily labeled and have a unique relationship to each other and to cells in their vicinity within the developing ganglion. On this basis, a cluster of labeled cells is traced in 10 animals with two to three animals being examined 


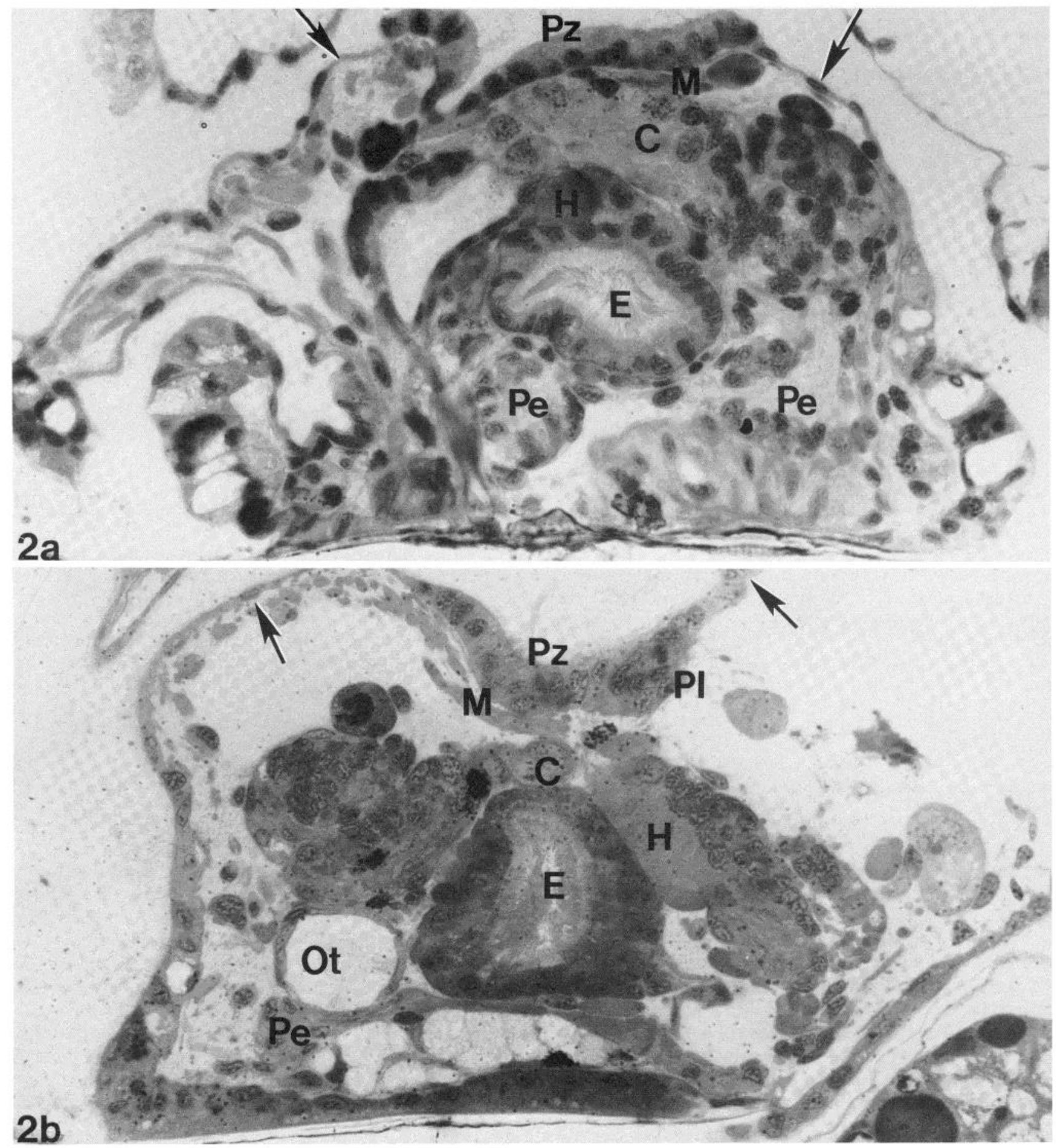

Figure 2. Proliferative zones in the body wall. Proliferative zones $(P z)$ are present in portions of the ciliated body wall which are adjacent to underlying mesodermal cells $(M)$ in $(a)$ a 24- and $(b)$ a 17-day-old Aplysia veliger. Cells of the proliferative zones have elongated to a columnar form as compared to the flat or cuboidal shape of ectodermal cells in other portions of the body wall (arrows). The nuclei are located at different levels within individual cells of the proliferative zones, giving these regions a pseudostratified appearance. $b$, A multilayered placode $(P l)$ is present in a central portion of the proliferative zone. Other indicated structures include the cerebral ganglion $(C)$, the pedal ganglia $(P e)$, the esophagus $(E)$, the heart $(H)$, and an otocyst $(O t)$. $a$ and $b$, Magnification $\times 400$.

each week for 4 weeks starting immediately following $\left[{ }^{3} \mathrm{H}\right]$ thymidine labeling of an egg mass in the late trochophore stage. One week following $\left[{ }^{3} \mathrm{H}\right]$ thymidine exposure, a cluster of four adjacent heavily labeled cells is observed in a column or stream extending inward from a proliferative zone in the right velar lobes of the two animals examined (Fig. 5a). Two weeks later a similar cluster of four labeled cells can be identified in three 


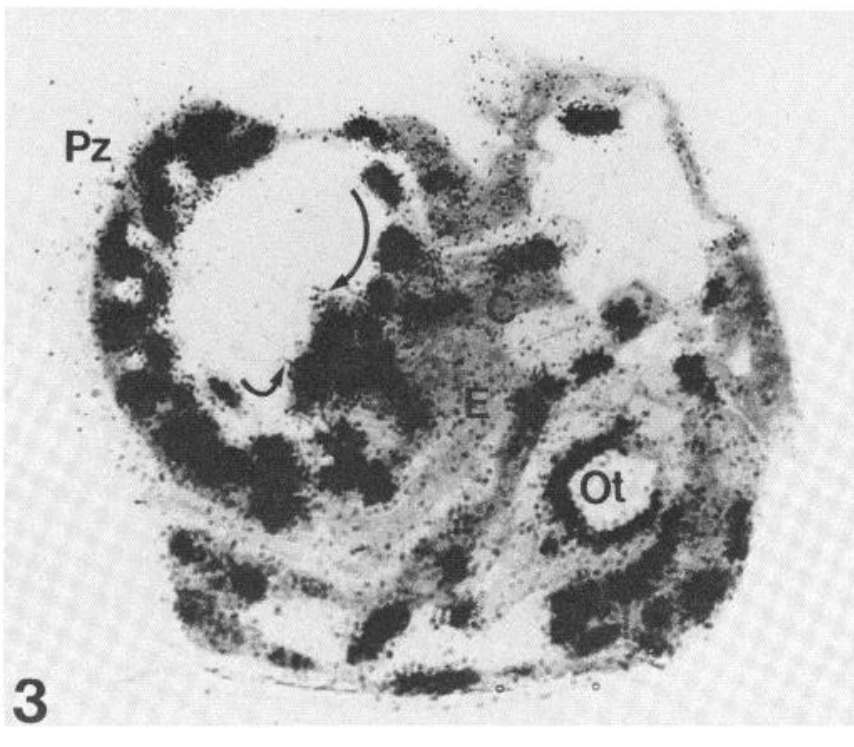

Figure 3. $\left[{ }^{3} \mathrm{H}\right]$ Thymidine labeling of proliferative zones. The cells of a multilayered, ciliated proliferative zone $(P z)$ of a newly hatched Aplysia veliger are heavily labeled following exposure of the gastrula to segmentation cavity stage egg mass to $\left[{ }^{3} \mathrm{H}\right]$ thymidine for $48 \mathrm{hr}$, rinsing for $24 \mathrm{hr}$, and maintenance in fresh sea water for 4 days. Some labeled cells detach from the surface and migrate along the inner surface of the body wall (arrows) to the nearby region of cerebral ganglion $(C)$ formation. Cells in other portions of the body wall and in such internal structures as the otocyst $(O t)$ and the esophagus $(E)$ are also heavily labeled at this stage. Magnification $\times 400$. animals within the superior border of the right pleural ganglion (Fig. $5 b$ ). The persistence of four heavily labeled cells within the ganglion suggests that the cells migrated as a group and did not undergo any further divisions after leaving the proliferative zone of the body wall.

A single labeled cell can be traced in a total of 24 animals examined over a range of developmental stages starting shortly following $\left[{ }^{3} \mathrm{H}\right]$ thymidine labeling of a late trochophore egg mass and extending to adult stages. The single labeled cell is present in the caudal segment of the left abdominal ganglion in all of the stages examined and is the only labeled cell present in this portion of the left abdominal ganglion in this experimental group (Fig. 6). Ultrastructural examination (EM-ARG) of early samples from this group suggests a pattern by which this cell joins the ganglion. Immediately following $\left[{ }^{3} \mathrm{H}\right]$ thymidine exposure of the late trochophore egg mass and rinsing, a small population of intensely radioactive cells is detected in the inferior caudal body wall. In an animal sampled 2 days later, a darkly staining immature cell is observed internal to the body wall near the region of caudal left abdominal ganglion formation. The migrating cell is characterized by a dense cytoplasm filled with free ribosomes and mitochondria, and numerous thin processes or pseudopodia extending out from the surface. One week following $\left[{ }^{3} \mathrm{H}\right]$ thymidine exposure, a labeled immature cell is found adjacent to one of the few cells forming the caudal left abdominal ganglion at this stage (Fig. 7).

\section{Additional morphological evidence relating to the origin}
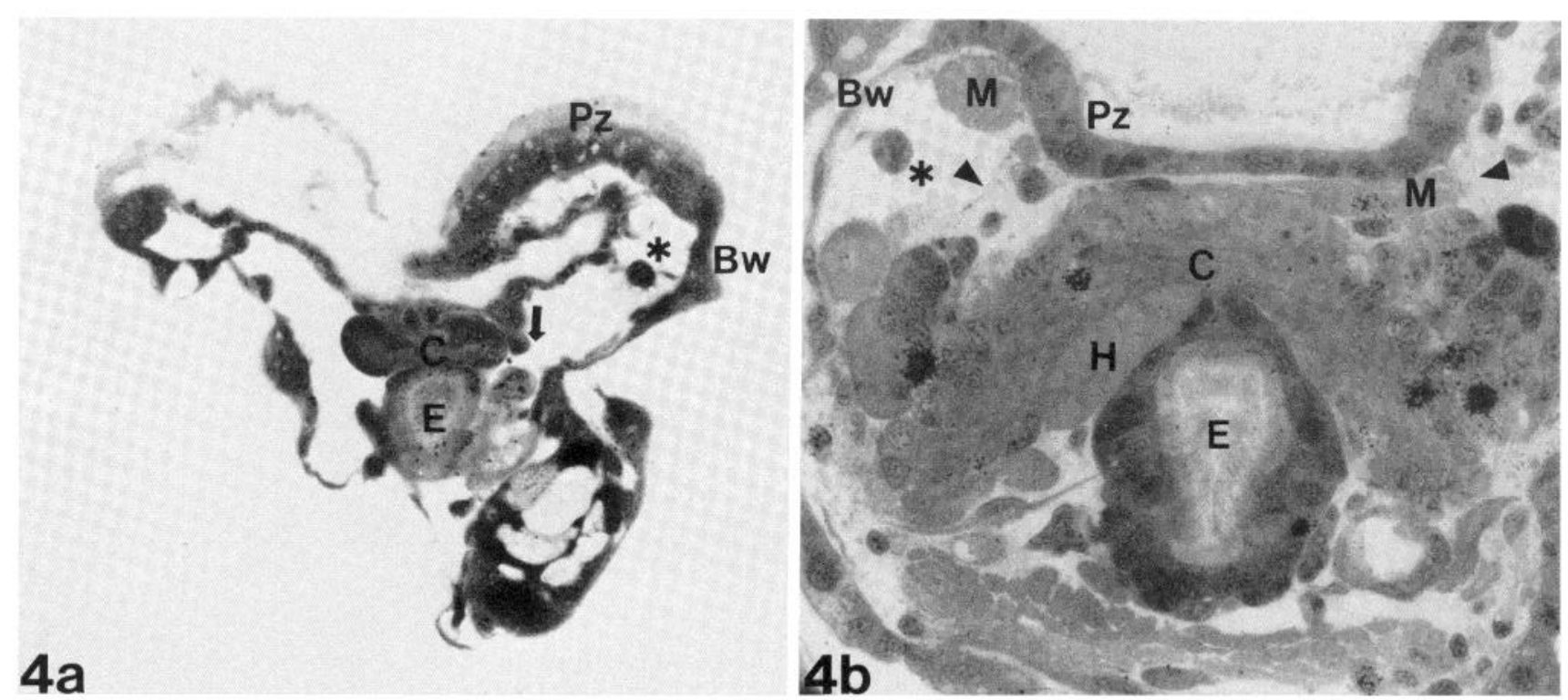

Figure 4. Two modes of migration: streaming and crawling. Cells detach from the proliferative zones $(P z)$ of the body wall and migrate as individuals or in small clusters by streaming or crawling. Cells which migrate by streaming (arrow) extend out from the body wall in a column or stream into the nearby region of the forming cerebral ganglion $(C)$ in this example from a newly hatched Aplysia veliger (a). The surface of the streaming cells is rounded and smooth. Cells which migrate by crawling (*) extend numerous fine processes from their surface $(a$ and $b$ ). The single cell migrating in the 17-day Aplysia veliger $(b)$ is undergoing mitosis. The processes of the crawling cells appear to contact the fibrous material of the inner surface of ectodermal cells in the body wall $(B w)$. Fine strands of extracellular matrix (arrowheads) are present within the spaces created by the expanding body wall $(b)$. Only a few fine strands of extracellular matrix are visible; however, no attempts were made to preserve it in the fixation process. The crawling cells are in the vicinity of the cerebral ganglion $(C)$. Other indicated structures include the heart $(H)$, the esophagus $(E)$, and muscle $(M)$. $a$ and $b$, magnification $\times 325$. 

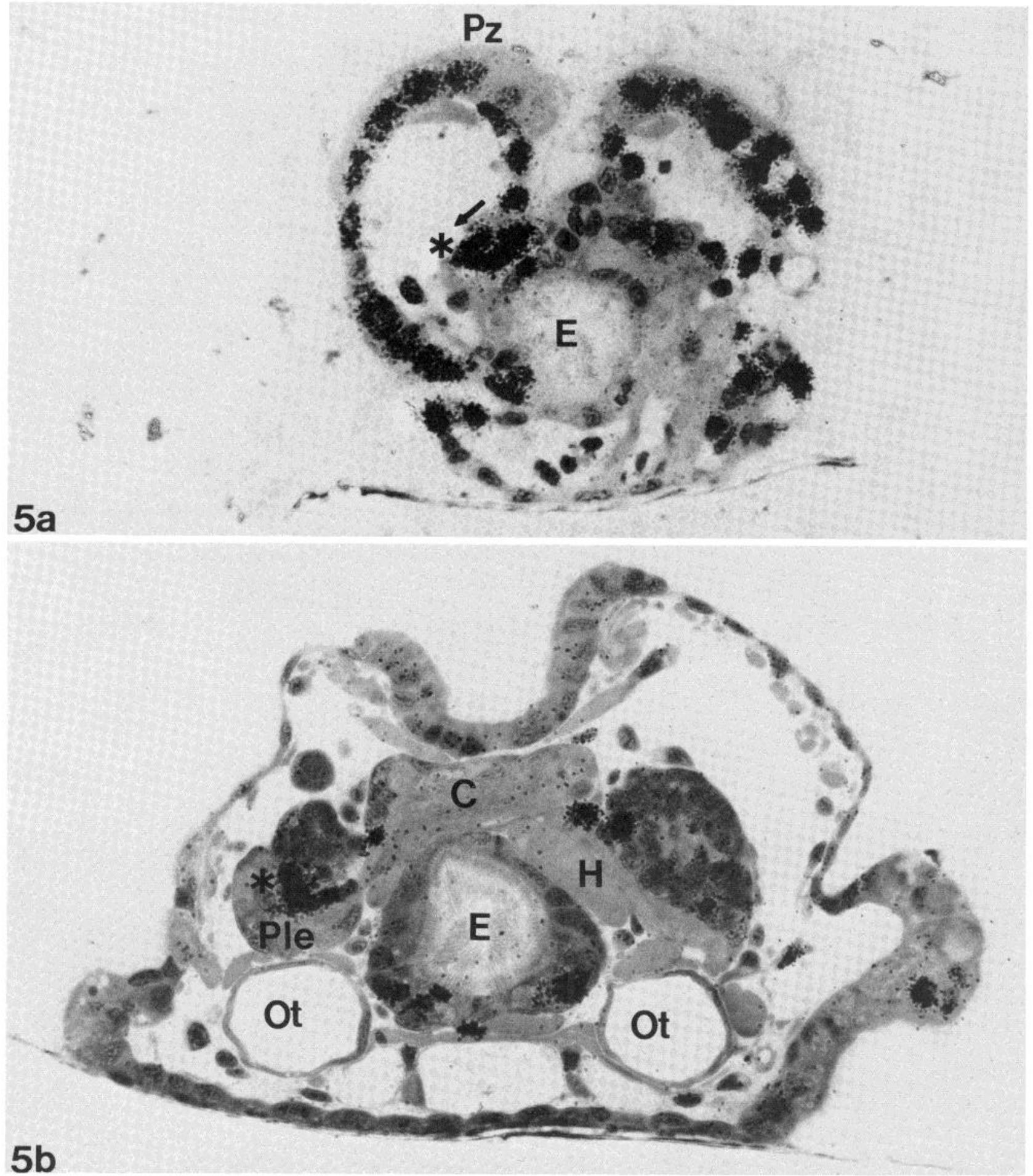

Figure 5. Tracing specific heavily labeled cells from the body wall to the nearby ganglion. $a$, A cluster of four adjacent heavily labeled cells $(*)$ is observed in a column or stream extending inward (arrow) from a proliferative zone $(P z)$ in the right velar lobe of an animal that had been labeled with $\left[{ }^{3} \mathrm{H}\right]$ thymidine for $48 \mathrm{hr}$ in the late trochophore egg mass stage, rinsed for $24 \mathrm{hr}$, maintained in fresh sea water for 1 week, fixed, and sectioned. $b$, A similar cluster of four adjacent heavily labeled cells $(*)$ is present within the superior border of the right pleural ganglion $(\mathrm{Ple})$ in an animal sampled 2 weeks later. The number of cells and the intensity of their radioactive labeling appear to be the same in the two animals. Other structures indicated include the cerebral ganglion $(C)$, the esophagus $(E)$, the heart $(H)$, and the otocysts $(O t) . a, \times 530 ; b, \times 440$.

of ganglionic cells. The ultrastructural appearance of some cells within individual ganglia further supports the model of cells of the Aplysia CNS being derived from ectodermal cells of the body wall. The ganglionic cells contain a cytoplasmic inclusion which appears to be an aggregation of cilia each containing nine outer doublets surrounding a central pair of microtubules, with some in varying degrees of disarray (Fig. $8 a$ ). Only cells which 

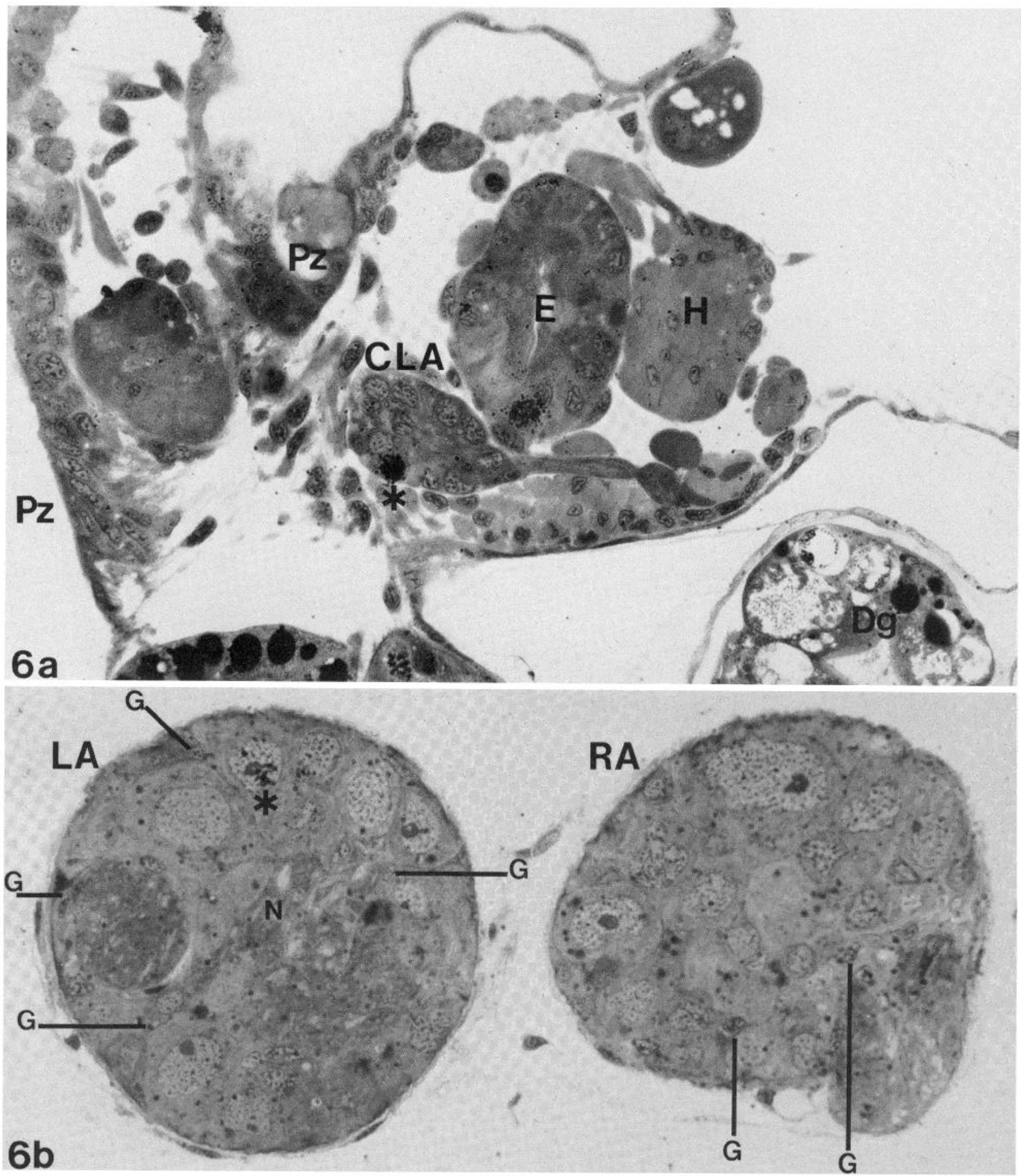

Figure 6. Tracing a single heavily labeled cell within the abdominal ganglion over time. $a$, A single labeled cell (*) is present in the caudal segment of the left abdominal ganglion $(C L A)$ of an animal that had been labeled with $\left[{ }^{3} \mathrm{H}\right]$ thymidine for $48 \mathrm{hr}$ in the late trochophore egg mass stage, rinsed for $24 \mathrm{hr}$, maintained in fresh sea water for 3 weeks, fixed, and serially sectioned. $b$, The same labeled cell $(*)$ can be identified in serial sections of the left abdominal ganglion $(L A)$ after the rostral and caudal segments have fused in an animal sampled 3 weeks following metamorphosis. This cell can be identified as a neuron at this stage (see the text). The $\left[{ }^{3} \mathrm{H}\right]$ thymidine labeling is less intense in the neuron of this postmetamorphic animal due to the increase in nuclear volume which dilutes the radioactive source. The neighboring small stellate glial cells $(G)$ have small oval nuclei that are not labeled. Other indicated structures include the right abdominal ganglion $(R A)$, the neuropil $(N)$, a proliferative zone $(P z)$, the esophagus $(E)$, the heart $(H)$, and the digestive gland $(D g) . a$, Magnification: $\times 400 ; b, \times 430$. 


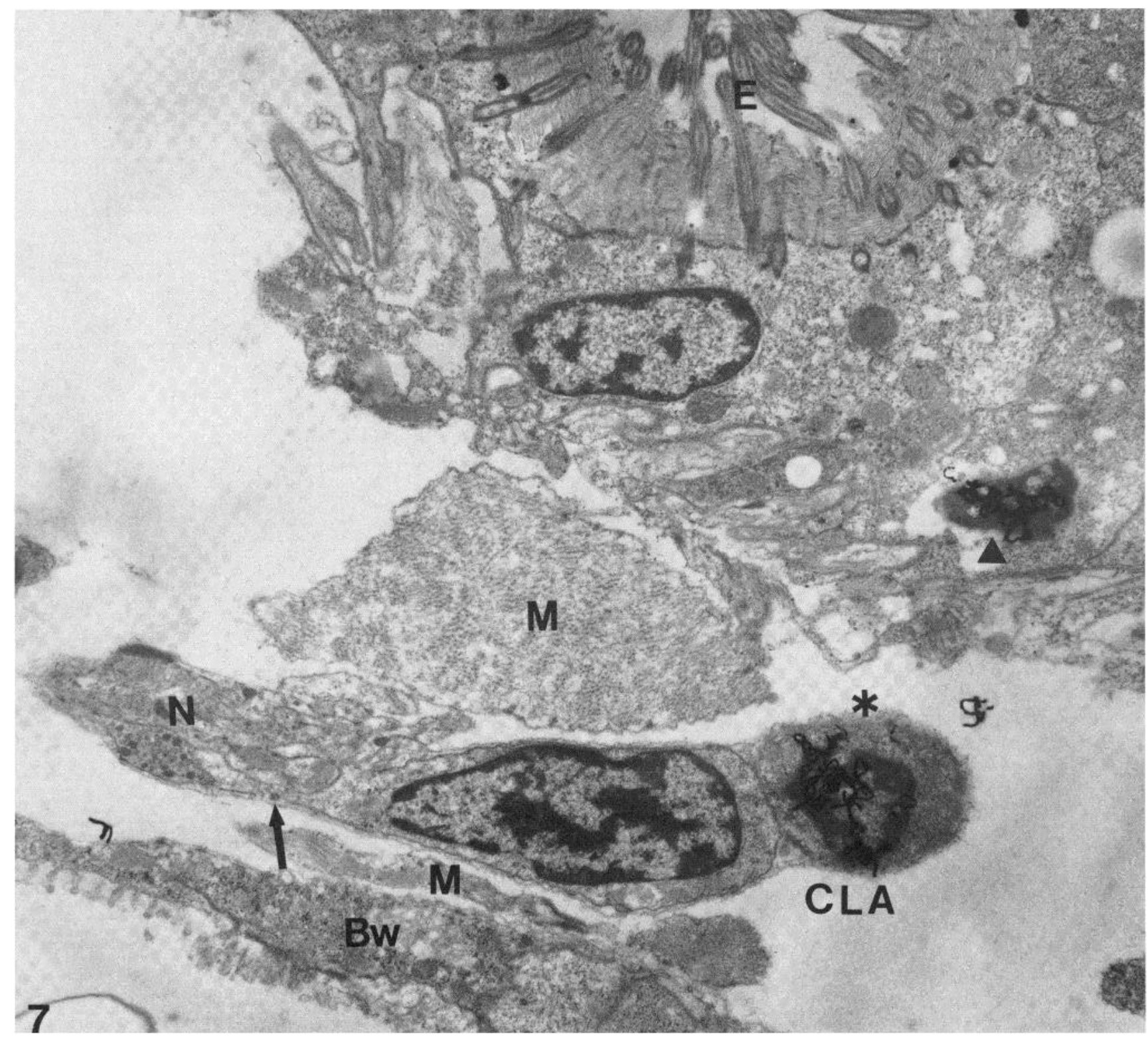

Figure 7. Ultrastructural localization of a single heavily labeled cell within the newly forming caudal segment of the left abdominal ganglion. A single labeled cell $(*)$ is present in the newly forming caudal segment of the left abdominal ganglion $(C L A)$ of an animal that had been labeled with $\left[{ }^{3} \mathrm{H}\right]$ thymidine for $48 \mathrm{hr}$ in the late trochophore egg mass stage, rinsed for $24 \mathrm{hr}$, maintained in fresh sea water for 1 week, fixed, serially sectioned in the region of the CLA, and processed for EM-ARG. The labeled immature cell has a dense cytoplasm containing numerous free ribosomes. The rounded shape and density of the cytoplasm distinguish this cell from the adjacent neuron, which appears to be sending a process $($ arrow) into the neuropil $(N)$ and is one of the few cells forming the CLA at this stage. A heavily labeled cell (arrowhead) is also present in the wall of the esophagus $(E)$. Other structures indicated include the ciliated body wall $(B w)$ and muscle $(M)$. Magnification $\times 35,300$.

are localized to the periphery of the forming ganglion contain the aggregated cilia, and, being on the periphery, these cells are adjacent to the proliferative zone of the body wall. Ectodermal cells in this region, as well as elsewhere in the body wall, are ciliated along their external surface, their cilia also being characterized by the 9 +2 pattern (Fig. $8 b$ ).

Sequence of individual ganglion formation. The distribution of newly arriving $\left[{ }^{3} \mathrm{H}\right.$ ]thymidine-labeled cells within the ganglia at successive developmental stages reflects the sequence of individual ganglion formation. Exposure of egg masses in the gastrula to segmentation cavity stage of embryonic development to $\left[{ }^{3} \mathrm{H}\right]$ thymidine results in the later appearance of a layer of heavily labeled cells along the superior-rostral surface of the cerebral ganglion. Labeling slightly more mature egg masses, as in the trochophore stage, results in the distribution of labeled cells along the lateral-caudal borders of the cerebral ganglion and spreading further into the pleural ganglion which forms as a lateral extension of the cerebral ganglion (Kriegstein, 1977b). This pattern suggests a rostral-to-caudal sequence of addition of new cells to the periphery of the individual forming ganglia that is similar to the rostral-to-caudal spatial and tem- 

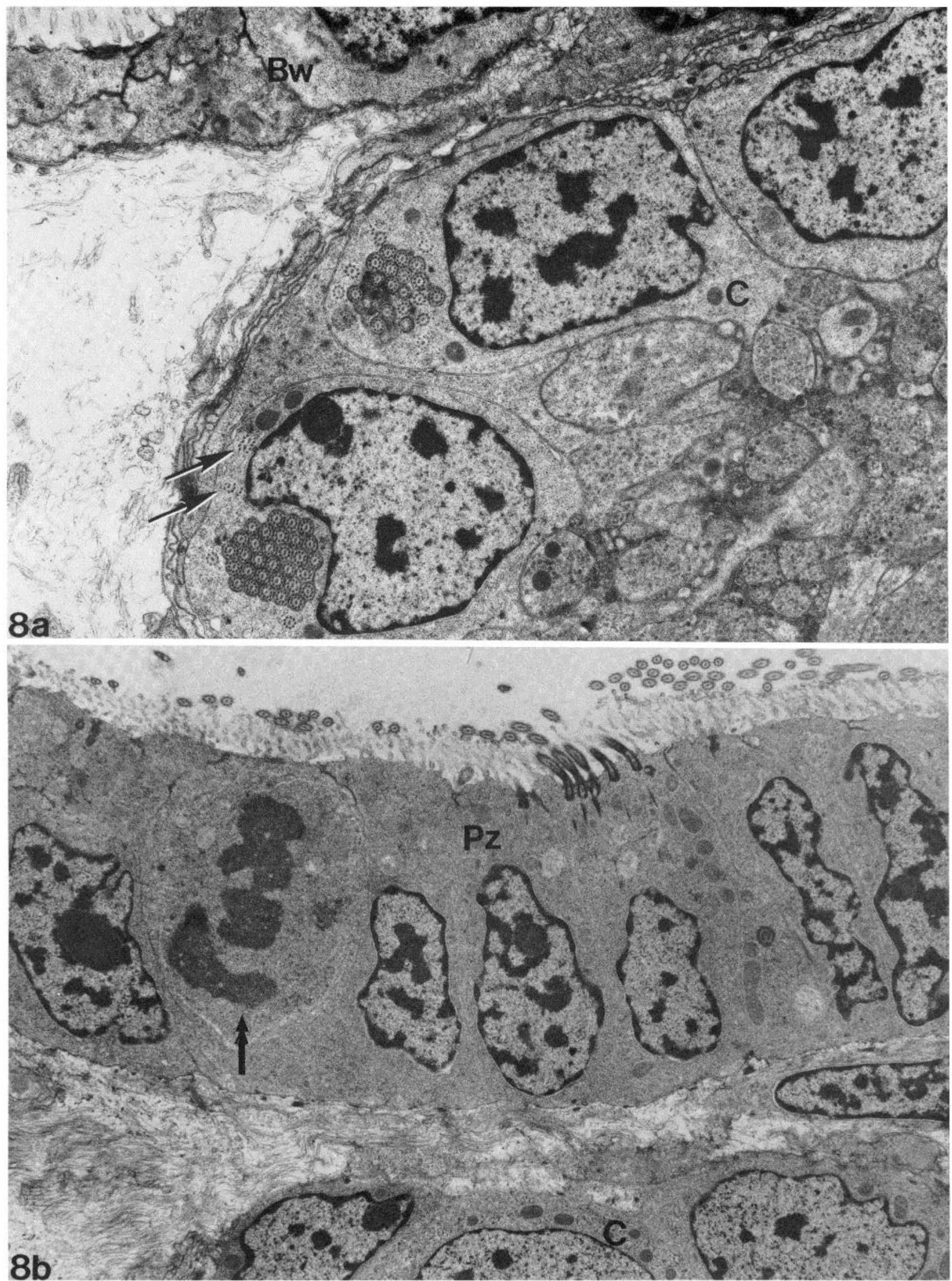

Figure 8. Aggregates of cilia within cells of a forming ganglion in early veliger stages. $a$, A number of cells of the forming cerebral ganglion $(C)$ of a 1-week-old Aplysia veliger contain an aggregation of cilia of the $9+2$ pattern of microtubule assembly within their cytoplasm. The cilia in the clusters appear to be in varying degrees of disarray with some cilia being disassembled into individual microtubules (arrows). The cells containing the aggregated cilia are in the periphery of the ganglion which is adjacent to the ciliated body wall $(B w) . b$, Columnar ectodermal cells of the proliferative zone $(P z)$ of the body wall contain cilia of the $9+2$ pattern of microtubule assembly along their external surface. A ciliated ectodermal cell of the proliferative zone is observed to be rounding up at its outer border as it undergoes mitosis (double arrow). A portion of the nearby cerebral ganglion (C) can be seen. Magnification: $a, \times 29,500 ; b, \times 23,300$. 

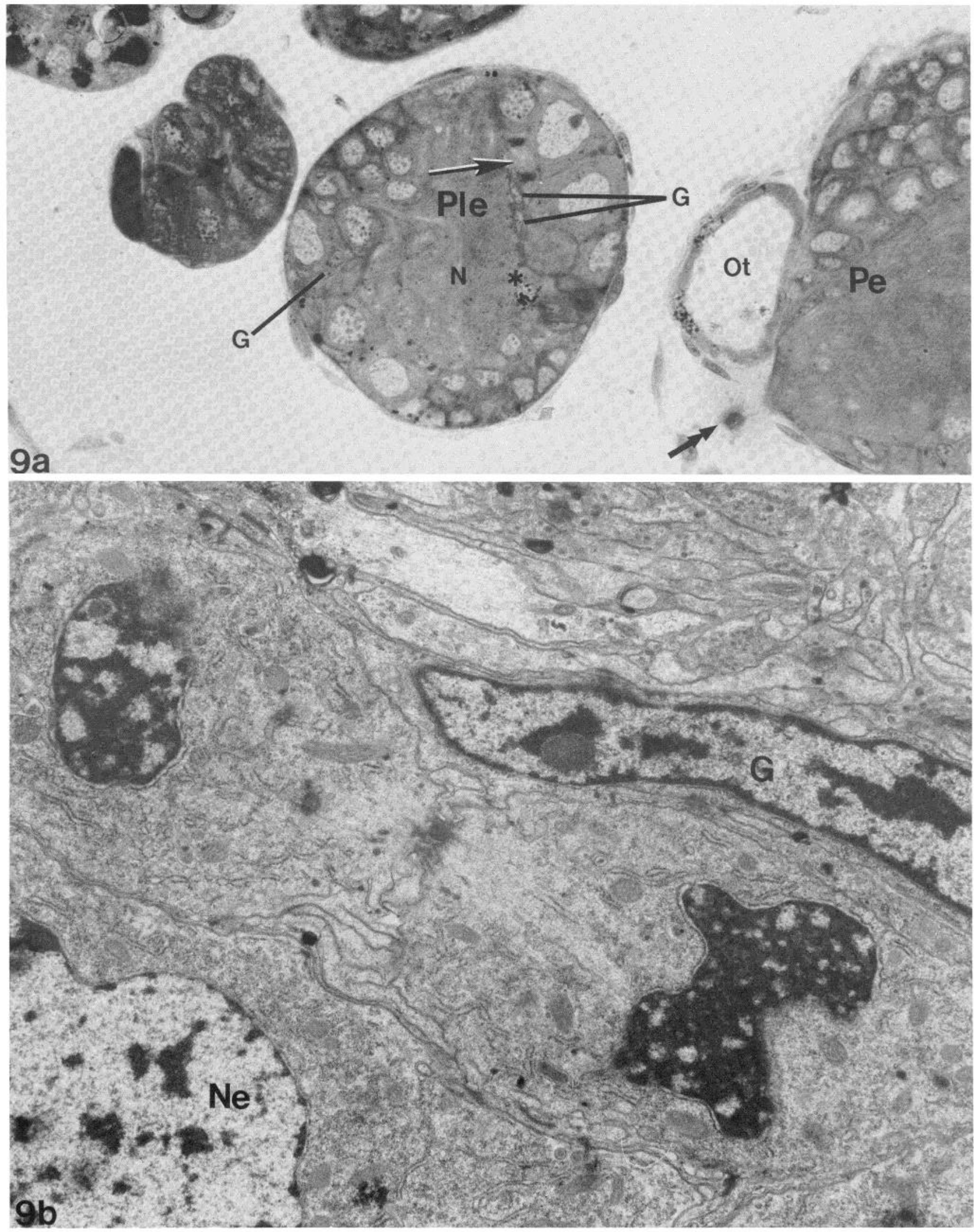

Figure 9. A mitotic cell in a juvenile ganglion. $a$, A cell at the border of the cell body layer and medullary neuropil $(N)$ of the pleural ganglion (Ple) of a 1-week postmetamorphic Aplysia juvenile is in mitosis (arrow). A neighboring cell with the morphological characteristics of a neuron $(*)$ is labeled, while the glial cells $(G)$ are not following exposure of the gastrula to segmentation cavity stage egg mass to $\left[{ }^{3} \mathrm{H}\right]$ thymidine for $48 \mathrm{hr}$, rinsing for $24 \mathrm{hr}$, maintenance in fresh sea water up to 1 week 
poral pattern of total CNS formation in Aplysia (Kriegstein, 1977b).

Identifying labeled cells as neurons in late stages. The identification of labeled cells within the Aplysia nervous system as neuronal or glial can be accomplished in animals in late developmental stages. Following metamorphosis, the cell bodies and nuclei of the neurons increase in volume while the cell bodies and nuclei of the glial cells do not (Kriegstein, 1977b; Schacher et al., 1979b). The one labeled cell present in the caudal left abdominal ganglion following exposure of the trochophore egg mass to $\left[{ }^{3} \mathrm{H}\right]$ thymidine can be identified as a neuron in juvenile stages (Fig. 6b). It is characterized by a large, clear, round nucleus that contains a distinct nucleolus and occupies a large portion of the total cell body volume as is typical of postmetamorphic neurons in Aplysia (Coggeshall, 1967).

Unfortunately, in the other experimental groups it is not possible to trace specific labeled cells to late stages of development due to the addition of new labeled cells to the ganglia. However, all of the ganglionic cells which remain labeled to juvenile stages in all experimental groups can be identified as neurons on the basis of their morphological characteristics and size (Figs. $6 b$ and $9 a$ ). The small oval nuclei of the neighboring small stellate glial cells are not labeled in these late stages, suggesting that they have divided a sufficient number of times in earlier stages to dilute their radioactivity to below detectable levels.

Cell generation by intraganglionic mitosis. Mitosis is infrequent in the developing Aplysia CNS. Serial sections of the entire nervous system in early embryo and veliger stages and of isolated abdominal ganglia in later juvenile and adult stages (each abdominal ganglion containing 1500 cells in the adult animal (Kandel, 1976)) of a total of 162 animals revealed only 13 mitoses. The dividing cells are in the periphery of the ganglia in early veliger stages and in the periphery and at the border of the cell body layer and medullary neuropil of ganglia in juvenile animals (Fig. 9). Cells in mitosis are also present in the proliferative zones of the body wall and in their vicinity as they migrate away, possibly to join nearby forming ganglia (Fig. 4b). Mitotic cells within the ganglia are not larger than adjacent nondividing cells, and cells observed in telophase appear to be dividing symmetrically (Fig. 9 ). No large precursor cells are present within the forming ganglia or within the proliferative zones of the body wall or their vicinity. In addition, no cell death has been observed within ganglia in this or earlier studies of the development of the Aplysia nervous system (A. R. Kriegstein and S. Schacher, personal communications).

In an attempt to distinguish the phenotype of the mitotic cells within the Aplysia CNS, their ultrastruc- tural characteristics have been determined. There appear to be two cell types capable of mitosis-immature cells and cells containing many of the morphological characteristics of glia. Immature dividing cells have a dense cytoplasm containing predominantly free ribosomes, polysomes, and mitochondria and are in the periphery of the ganglia of veliger stages. Other cell types in mitosis have also been observed in the periphery and at the border of the cell body layer and medullary neuropil of juvenile ganglia (Fig. 9). These cells are small; their average nuclear diameter, as observed in telophase, more closely approximates that of the surrounding glial cells rather than the larger nuclei of the neurons. The cytoplasmic contents of the dividing cells also resemble glial cells, containing scattered dilated cisternae of rough endoplasmic reticulum (rer), small Golgi complexes, large mitochondria, many free ribosomes, polysomes, and several smooth-membraned vacuoles and vesicles (Fig. 9b). The adjacent glial cells are small cells whose cytoplasm contains scattered dilated cisternae of rer, small Golgi complexes, large mitochondria, several smooth-membraned vacuoles and vesicles, multivesicular bodies, lysosomes, many free ribosomes, polysomes, and glycogen granules in some of the glial cells (Fig. 10). In comparison, the neurons are much larger cells whose cytoplasm contains long narrow cisternae of rer, prominent Golgi complexes with several associated small dense vacuoles, numerous clear smooth-membraned vacuoles and vesicles, neurotubules, multivesicular bodies, lysosomes, small mitochondria, many free ribosomes, and polysomes (Fig. 10).

\section{Discussion}

The formation of the CNS of $A$. californica occurs as a gradual, continuous process over approximately 140 days, beginning in the early egg mass and continuing through the juvenile stage (this study; Kriegstein, 1977a; for review see Kandel et al., 1980). This is a relatively long period of time for the generation of a relatively small number of cells. $\left[{ }^{3} \mathrm{H}\right]$ Thymidine exposure of developmental stages from gastrulation on results in the presence of labeled cells within the various forming ganglia.

During gastrulation, a portion of the ectoderm folds in, leading to the formation of the primary gut and positioning the newly forming mesoderm between the endoderm and ectoderm (Saunders and Poole, 1910). Ectodermal cells adjacent to underlying mesodermal cells change from a flat or cuboidal state to a columnar shape. This is consistent with the idea that differentiation of the neuroectoderm is induced by mesoderm (Spemann and Mangold, 1924; Saxen, 1980). The elongation to a columnar form may depend on the orientation of intracellular organelles, such as microtubules (Karfunkel,

following metamorphosis, and processing for LM-ARG. Labeled cells are also present in the otocyst (Ot) located above the pedal ganglion $(P e)$. A cell with numerous fine processes extending from its surface (double arrow). is present in the vicinity of the pedal ganglion. $b$, Ultrastructural examination of a thin section taken following re-embedding of the thick section shown in $a$ reveals that the mitosing cell cytoplasm contains scattered dilated cisternae of rough endoplasmic reticulum, a small Golgi complex, large mitochondria, many free ribosomes, polysomes, and several smooth-membraned vacuoles and vesicles. The mitosing cell, which is in late telophase, is separating into two small symmetrical cells whose nuclear diameter as the nuclear envelope reappears more closely approximates that of the adjacent glial cell $(G)$ rather than the large nucleus of the neuron $(\mathrm{Ne})$. Magnification: $a, \times 380 ; b, \times 35,000$. 


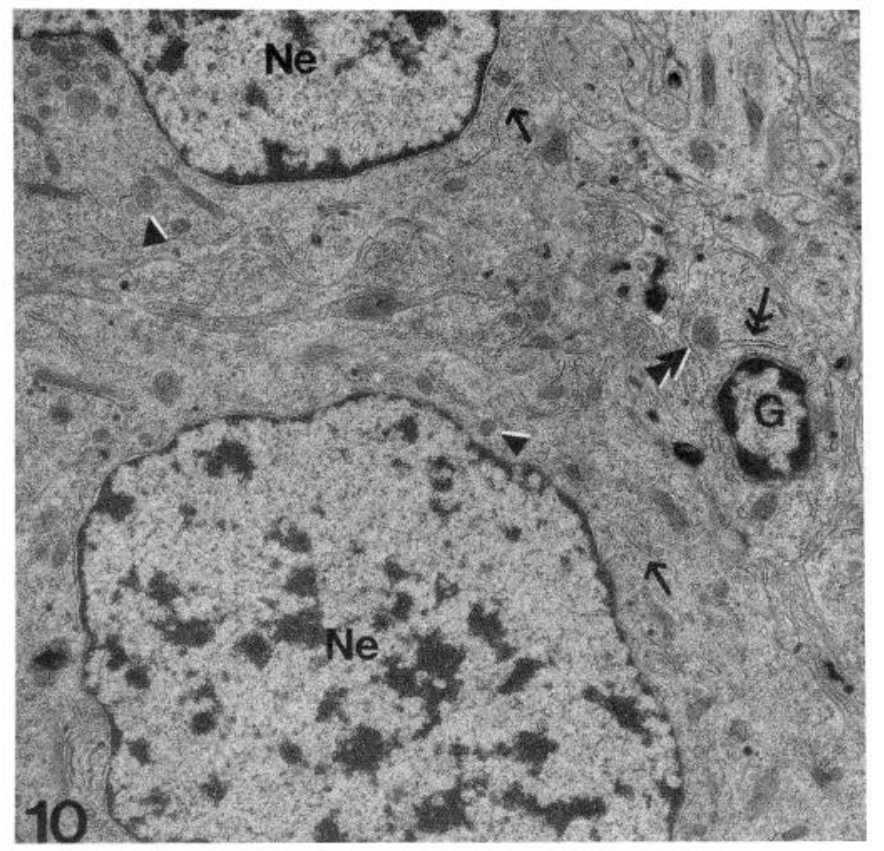

Figure 10. Ultrastructural characteristics of glial and neuronal cells. Glial cells $(G)$ are small cells with small, dense, oval nuclei. Their cytoplasm contains scattered dilated cisternae of rer (double arrow), small Golgi complexes, large mitochondria (double arrowhead), several smooth-membraned vacuoles and vesicles, multivesicular bodies, lysosomes, many free ribosomes, polysomes, and, occasionally, glycogen granules. In comparison, the neurons $(\mathrm{Ne})$ are much larger cells with large, clear, round nuclei and a cytoplasm containing long narrow cisternae of rer (arrows), prominent Golgi complexes with several associated small dense vacuoles, small mitochondria (arrowheads), numerous clear smooth-membraned vacuoles and vesicles, neurotubules, multivesicular bodies, lysosomes, many free ribosomes, and polysomes. Magnification $\times 26,600$.

1971), which may also influence the direction of subsequent cell divisions. The columnar ectodermal cells undergo frequent mitoses, forming proliferative zones in the body wall. Cell division in the absence of rapid migration generates multilayered placodes in the central regions of the proliferative zones. Both the columnar and placodal cells contribute to a population of $\left[{ }^{3} \mathrm{H}\right]$ thymidine-labeled cells which are capable of migration. Cells generated in the proximal ectodermal placodes extend in ca column or stream from the innermost layer into the nearby region of ganglion formation. The close packing of cells in the rows of the placodes may act as a physical barrier, forcing cells of the innermost layer to slough off and extend inward. Cells generated in the more distal columnar regions of the proliferative zones have numerous processes or pseudopodia which contact neighboring ectodermal cells, muscle, and extracellular matrix. The difference in origin of the migrating cells, i.e., distal columnar versus proximal placodal ectoderm, might determine the mode of migration and the pathway along which the cells travel. Additionally, it may affect the phase of the cell cycle within which the cells leave the body wall, the time required to complete migration, and the ultimate fate of the cells. Investigations of the formation of avian sensory cranial ganglia have demonstrated differences between cells derived from the neural crest and the placodal ectoderm in regard to the time the cells withdraw from the cell cycle and the cell type formed within the various ganglia (Hamburger, 1961; D'AmicoMartel and Noden, 1980; Narayanan and Narayanan, 1980). Unfortunately, it is not possible to determine whether these correlations also exist in Aplysia since $\left[{ }^{3} \mathrm{H}\right]$ thymidine labeling does not distinguish placodal and columnar cell derivatives within the ganglia.

Tracing labeled cells as they migrate from the proliferative zones to specific ganglia favors a model of columnar and placodal cell proliferation as the major source of the neurons and glia of the Aplysia CNS. In the case of the single labeled cell in the caudal left abdominal ganglion and the four labeled cells in the pleural ganglion, it is clear that these cells do not divide within the ganglia because the intensity of the radioactive label in their nuclei does not change and neither does the number of labeled cells in their vicinity over time. In general, however, monitoring changes in the number of labeled cells within specific ganglia over time is complicated by the constant addition of new labeled cells and by the presence of polyploid neurons within the Aplysia CNS. Polyploid neurons replicate their DNA numerous times in the absence of subsequent nuclear or cell division. Polyploid neurons have been identified in the abdominal, pleural, and cerebral ganglia of the adult Aplysia CNS (Coggeshall et al., 1970; Lasek and Dower, 1971; Treistman and Schwartz, 1976) and are known to undergo increases in nuclear volume which are roughly correlated with the degree of polyploidy (Coggeshall et al., 1970). No large labeled or unlabeled cells have been observed in the premetamorphic Aplysia CNS, the increases in nuclear and cellular volume being observed to occur in postmetamorphic stages which were not exposed to $\left[{ }^{3} \mathrm{H}\right]$ thymidine in this study.

The contribution of ectodermal cell proliferation to CNS formation in Aplysia is also demonstrated by the presence of cilia of a $9+2$ configuration within ganglion cells which are adjacent to proliferating ectodermal cells containing cilia of a $9+2$ configuration along their external border. The $9+2$ pattern is the standard configuration for cilia of non-neuronal cells of the body, whereas a $9+0$ pattern characterizes the cilia of neuronal cells in other animals (Peters et al., 1976). I propose that the cilia of the ectodermal cells of the proliferative zone are internalized at some point during mitosis and migration and subsequently appear as aggregates within the cytoplasm of cells within the ganglion. The breakdown and conversion of the cilia into individual microtubules appear to be occurring and may reflect a function in the migration of the cells to the ganglion and in such later processes as axon elongation. A small number of cilia have also been observed within a few immature neurons of the vertebrate nervous system and have been suggested to reflect the origin of these cells from the ciliated epithelium of the neural tube and neural crest (Lyser, 1968; Peters et al., 1976; Tosney, 1982).

The contribution of intraganglionic cell proliferation to CNS formation in Aplysia is limited and predominantly involves glial cells. Mitoses are infrequent in the Aplysia CNS. The morphological features of the few dividing cells suggest that some of the cells undergoing mitosis in the periphery of the ganglia are immature 
while the other dividing cells in the periphery and those along the inner border of the cell body layer appear to be glial cells. The interpretation that the glial cells continue to divide is supported by the absence of $\left[{ }^{3} \mathrm{H}\right]$ thymidine labeling of the small nuclei of the glial cells in juvenile and adult ganglia of all experimental animals. In contrast, the evidence suggests that the final genomic replication of the neuronal precursors occurs before the cells join the ganglia with the cell cycle being completed while the cell is in the body wall, during migration, or in the peripheral border of the ganglion.

A number of parallels exist between the present model of neurogenesis of the Aplysia CNS and the proliferation of cells in the neural tube and the migration of neural crest and ectodermal placode cells in the vertebrate CNS and PNS. The early neural tube consists of columnar ectodermal cells which divide to ultimately give rise to the neurons and glia of the vertebrate CNS (Lyser, 1964; see reviews by Angevine, 1970; Sidman, 1970; Cowan, 1978). Both the columnar ectodermal cells of the vertebrate neural tube and the columnar ectodermal cells of the proliferative zones of the Aplysia body wall are ciliated, have a pseudostratified appearance, and round up at their ventricular or outer surface when they divide (this study; Sauer, 1935; Lyser, 1964; Angevine, 1970; Cowan, 1978). In both the vertebrate and the Aplysia CNS, the majority of immature ncurons withdraw from the mitotic cycle and then migrate to the developing neural structure, while most of the glial cells continue to divide during and after migration (this study; Angevine, 1970; Sidman, 1970; Skoff et al., 1976; Cowan, 1978).

The two modes of migration of cells derived from the columnar and placodal ectoderm of the Aplysia body wall resemble the migration of neural crest and ectodermal placode cells, respectively, in the vertebrate nervous system. Neural crest and ectodermal placode cells form the sensory cranial ganglia and the sensory and autonomic ganglia of the vertebrate nervous system (Yates, 1961; Weston, 1970; Cohen, 1974; Cowan, 1978; Noden, 1978; D'Amico-Martel and Noden, 1980). Similar to cells migrating from distal columnar portions of the proliferative zones in Aplysia, vertebrate neural crest cells migrate as individuals or in small clusters with the cells extending numerous long slender processes which contact the extracellular matrix of the cell-free spaces between the ectoderm and mesoderm, and the basal laminae of the ectoderm, mesoderm, and neural tube (Weston, 1970; Pratt et al., 1975; Leikola, 1976; Cowan, 1978; Noden, 1978; Tosney, 1978; Lofberg et al., 1980; Noden, 1980; Tosney, 1982). Similar to the migration of cells generated in the central placodal regions of the proliferative zones of Aplysia, vertebrate ectodermal placode cells appear to delaminate from the deeper layers of the ectodermal thickenings and extend as a column or stream in to the nearby forming neural structure (Stone, 1933; Batten, 1957; Weston, 1970). In particular, the migration of both neural crest and ectodermal placode cells to the sensory cranial ganglia in the vertebrate resembles CNS formation by columnar and placodal cells in the Aplysia with the pattern of proliferation resembling the vertebrate neural tube.

Neurogenesis of the Aplysia CNS differs from the pattern observed in other invertebrates, such as the leech, nematode, and holo- and hemimetabolous insects, where proliferation of ectodermal cells in the body wall results in the formation of large precursor cells which undergo numerous asymmetrical divisions to generate a series of smaller progeny in the segmental ganglia of the CNS (Nordlander and Edwards, 1969; Anderson, 1972a, b; Bate, 1976; Sulston, 1976; Sulston and Horvitz, 1977; White and Kankel, 1978; Anderson et al., 1980; Weisblat et al., 1980; Goodman et al., 1981; Stent et al., 1982). The smaller cells differentiate, in the insects and leech after dividing at least one time, to postmitotic immature neurons or to glial cells which continue to replicate for some time (Gymer and Edwards, 1967; Nordlander and Edwards, 1969; Bate, 1976; Sulston, 1976; Sulston and Horvitz, 1977; White and Kankel, 1978; Goodman et al., 1981; Stent et al., 1982). Another class of neuronal precursor cell has been described, the midline precursor cell in the grasshopper, which divides once in the ganglionic anlagen to generate two neurons, one or both of which die after serving a central pioneering role (Goodman et al., 1981). Specific cells of the segmental ganglia in nematodes and the large neuroblast cells of insects which do not proliferate during metamorphosis also die (Bate, 1976; Sulston, 1976; Sulston and Horvitz, 1977; Anderson et al., 1980; Goodman et al., 1981). This pattern of neurogenesis of the insect, leech, and nematode CNS differs from the formation of the Aplysia CNS where large neuroblasts or precursor cells are not observed in the body wall, migrating, or in the developing ganglia. Cell division in these areas appears to be infrequent and symmetrical, and no cell death has been observed. In addition, immature neurons of the Aplysia CNS appear to withdraw from the cell cycle prior to leaving the proliferative zones of the body wall as contrasted to the extensive proliferation of neuroblasts during migration and in the forming neural structure in the other invertebrates.

The similarities between neurogenesis of the CNS in Aplysia and the proliferation of cells in the neural tube and the migration of neural crest and ectodermal placode cells in the vertebrate nervous system are particularly striking in comparison to the pattern of neurogenesis in other invertebrates. One possible explanation for the similarity of neurogenesis in Aplysia to gangliogenesis in vertebrates and the differences between neurogenesis in Aplysia and the other invertebrates may be the absence of a repeating segmental organization in the Aplysia CNS as in the vertebrate sensory cranial ganglia. The pattern of occasional symmetrical mitoses of ectodermal cells in the proliferative zones of the body wall over an extended period of time as seen in Aplysia may characterize the formation of a CNS containing a small number of ganglia with specialized, well defined, nonoverlapping functions.

\section{References}

Anderson, D. T. (1972a) The development of hemimetabolous insects. In Developmental Systems: Insects, S. J. Counce and C. H. Waddington, eds., Vol. I, pp. 95-163, Academic Press, London.

Anderson, D. T. (1972b) The development of holometabolous insects. In Developmental Systems: Insects, S. J. Counce and C. H. Waddington, eds., Vol. I, pp. 165-242, Academic Press, London. 
Anderson, H., J. S. Edwards, and J. Palka (1980) Developmental neurobiology of invertebrates. Annu. Rev. Neurosci. 3: $97-139$.

Angevine, J. B., Jr. (1970) Critical cellular events in the shaping of neural centers. In The Neurosciences Second Study Program, F. O. Schmitt and T. Melnechuck, eds., pp. 62-72, Rockefeller University Press, New York.

Bate, C. M. (1976) Embryogenesis of an insect nervous system I. A map of the thoracic and abdominal neuroblasts in Locusta migratoria. J. Embryol. Exp. Morphol. 35: 107-123.

Batten, E. H. (1957) The activity of the trigeminal placode in the sheep embryo. J. Anat. 91: 174-187.

Cleaver, J. E. (1967) Thymidine metabolism: Pathways of incorporation and degradation. In Thymidine Metabolism and Cell Kinetics, pp. 43-70, North Holland Publishing Co., Amsterdam.

Coggeshall, R. E. (1967) A light and electron microscope study of the abdominal ganglion of Aplysia californica. J. Neurophysiol. 30: 1263-1287.

Coggeshall, R. E., B. A. Yaksta, and F. J. Swartz (1970) A cytophotometric analysis of the DNA in the nucleus of the giant cell, R-2, in Aplysia. Chromosoma 32: 205-212.

Cohen, A. M. (1974) DNA synthesis and cell division in differentiating avian adrenergic neuroblasts. In Dynamics of Degeneration and Growth in Neurons, K. Fuxe, L. Olson, and Y. Zotterman, eds., pp. 359-370, Pergamon Press, New York.

Cowan, W. M. (1978) Aspects of neural development. Int. Rev. Physiol. 17: 149-191.

D'Amico-Martel, A., and D. M. Noden (1980) An autoradiographic analysis of the development of the chick trigeminal ganglion. J. Embryol. Exp. Morphol. 55: 167-182.

Goodman, C. S., M. Bate, and N. C. Spitzer (1981) Embryonic development of identified neurons: Origin and transformation of the H cell. J. Neurosci. 1: 94-102.

Gymer, A., and J. S. Edwards (1967) The development of the insect nervous system. I. An analysis of postembryonic growth in the terminal ganglion of Acheta domesticus. J. Morphol. 123: 191-198.

Hamburger, V. (1961) Experimental analysis of the dual origin of the trigeminal ganglion in the chick embryo. J. Exp. Zool. 148: 91-124.

Kandcl, E. R. (1976) Cellular Basis of Behavior: An Introduction to Behavioral Neurobiology, W. H. Freeman, San Francisco.

Kandel, E. R. (1979) Behavioral Biology of Aplysia, W. H. Freeman, San Francisco.

Kandel, E. R., A. Kriegstein, and S. Schacher (1980) Development of the central nervous system of Aplysia in terms of the differentiation of its specific identifiable cells. Neuroscience 5: 2033-2063.

Kandel, P., and 'T. R. Capo (1979) The packaging of ova in the egg cases of Aplysia californica. Veliger 22: 194-198.

Karfunkel, P. (1971) The role of microtubules and microfilaments in neurulation in Xenopus. Dev. Biol. 25: 30-56.

Kimmel, C. B., S. K. Sessions, and R. J. Kimmel (1978) Radiosensitivity and time of origin of Mauthner neurons in the zebra fish. Dev. Biol. 62: 526-529.

Kriegstein, A. R. (1977a) Stages in the post-hatching development of Aplysia californica. J. Exp. Zool. 199: 275-288.

Kriegstein, A. R. (1977b) Development of the nervous system of Aplysia californica. Proc. Natl. Acad. Sci. U. S. A. 74: 375378.

Kriegstein, A. R., V. Castellucci, and E. R. Kandel (1974) Metamorphosis of Aplysia californica in laboratory culture. Proc. Natl. Acad. Sci. U. S. A. 71: 3654-3658.

Lamborghini, J. E. (1980) Rohon-Beard cells and other large neurons in Xenopus embryos originate during gastrulation. J. Comp. Neurol. 189: 323-333.

Lasek, R. J., and W. J. Dower (1971) Aplysia californica: Analy- sis of nuclear DNA in individual nuclei of giant neurons. Science 172: 278-280.

Leibowitz, D. (1976) Propylene phenoxytol-magnesium chloride method for narcotizing gastropod veligers. In Laboratory Methods in the Study of Marine Zooplankton, H. F. Steedman, ed., pp. 301-304, UNESCO Monograph on Oceanographic Methodology, No. 4.

Leikola, A. (1976) The neural crest: Migrating cells in embryonic development. Folia Morphol. 24: 155-172.

Lofberg, J., K. Ahlfors, and C. Fallstrom (1980) Neural crest cell migration in relation to extracellular matrix organization in the embryonic axolotl trunk. Dev. Biol. 75: 148-167.

Lyser, K. M. (1964) Early differentiation of motor neuroblasts in the chick embryo as studied by electron microscopy $\mathrm{I}$. General aspects. Dev. Biol. 10: 433-466.

Lyser, K. M. (1968) An electron-microscope study of centrioles in differentiating motor neuroblasts. J. Embryol. Exp. Morphol. 20: 343-354.

Narayanan, C. H., and Y. Narayanan (1980) Neural crest and placodal contributions in the development of the glossopharyngeal-vagal complex in the chick. Anat. Rec. 196: 71-82.

Noden, D. M. (1978) Interactions directing the migration and cytodifferentiation of avian neural crest cells. In Specificity of Embryological Interactions, Receptors and Recognition, Series $B$, D. R. Garrod, ed., Vol. 4, pp. 3-49, Chapman and Hall, London.

Noden, D. M. (1980) The migration and cytodifferentiation of cranial neural crest cells. In Current Research Trends in Prenatal Craniofacial Development, R. M. Pratt and R. L. Christiansen, eds., pp. 3-25, Elsevier-North Holland Publishing Co., New York.

Nordlander, R. H., and J. S. Edwards (1969) Postembryonic brain development in monarch butterfly Danaus plexippus plexippus, L. I. Cellular events during brain morphogenesis. W. Roux Archiv, 163: 197-220.

Peters, A., S. L. Palay, and H. deF. Webster (1976) The neuronal cell body, cilia and centrioles. In The Fine Structure of the Nervous System, pp. 42-43, W. B. Saunders Co., Philadelphia.

Pratt, R. M., M. A. Larsen, and M. C. Johnston (1975) Migration of cranial neural crest cells in a cell-free hyaluronaterich matrix. Dev. Biol. 44: 298-305.

Sauer, F. C. (1935) Mitosis in the neural tube. J. Comp. Neurol. 62: 377-405.

Saunders, A. M. C., and M. Poole (1910) The development of Aplysia punctata. Q. J. Microsc. Sci. 55: 497-540.

Saxen, L. (1980) Neuronal induction: Past, present and future. Curr. Top. Dev. Biol. 15: 409-418.

Schacher, S., E. R. Kandel, and R. Woolley (1979a) Development of neurons in the abdominal ganglion of Aplysia californica. I. Axosomatic synaptic contacts. Dev. Biol. 71: 163175 .

Schacher, S., E. R. Kandel, and R. Woolley (1979b) Development of neurons in the abdominal ganglion of Aplysia californica. II. Nonneural supports cells. Dev. Biol. 71: 176-190.

Sidman, R. L. (1970) Autoradiographic methods and principles for study of the nervous system with thymidine- $\mathrm{H}^{3}$. In Contemporary Research Methods in Neuroanatomy, W. J. H. Nauta and S. O. E. Ebbesson, eds., pp. 252-274, SpringerVerlag, New York.

Skoff, R. P., D. L. Price, and A. Stocks (1976) Electron microscopic autoradiographic studies of gliogenesis in rat optic nerve. I. Cell proliferation. J. Comp. Neurol. 169: 291-312.

Spemann, H., and H. Mangold (1924) Induction of embryonic primordia by implantation of organizers from a different species. Wilhelm Roux Arch. Entwickslungmech. Organ. 100: 599-639.

Stent, G. S., D. A. Weisblat, S. S. Blair, and S. L. Zackson 
(1982) Cell lineage in the development of the leech nervous system. In Neuronal Development, N. C. Spitzer, ed., pp. 144, Plenum Press, New York.

Stone, L. S. (1933) The development of lateral-line sense organs in amphibians observed in living and vital-stained preparations. J. Comp. Neurol. 57: 507-540.

Sulston, J. E. (1976) Post-embryonic development in the ventral cord of Caenorhabditis elegans. Philos. Trans. R. Soc. Lond. Biol. 275: 287-297.

Sulston, J. E., and H. R. Horvitz (1977) Post-embryonic cell lineages of the nematode Caenorhabditis elegans. Dev. Biol. 56: $110-156$.

Thompson, E. B., J. H. Schwartz, and E. R. Kandel (1976) A radioautographic analysis in the light and electron microscope of identified Aplysia neurons and their processes after intrasomatic injection of $\mathrm{L}-\left[{ }^{3} \mathrm{H}\right]$ fucose. Brain Res. 112: 251281.

Tosney, K. W. (1978) The early migration of neural crest cells in the trunk region of the avian embryo: An electron microscopic study. Dev. Biol. 62: 317-333.
Tosney, K. W. (1982) The segregation and early migration of cranial neural crest cells in the avian embryo. Dev. Biol. 89: $13-24$.

Treistman, S. N., and J. H. Schwartz (1976) Functional constancy in Aplysia nervous systems with anomalously duplicated identifed neurons. Brain Res. 109: 607-614.

Vargas-Lizardi, P., and K. M. Lyser (1974) Time of origin of Mauthner's neuron in Xenopus laevis embryos. Dev. Biol. 38: 220-228.

Weisblat, D. A., G. Harper, G. S. Stent, and R. T. Sawyer (1980) Embryonic cell lineages in the nervous system of the glossiphoniid leech, Helobdella triserialis. Dev. Biol. 76: 5878.

Weston, J. A. (1970) The migration and differentiation of neural crest cells. Adv. Morphogen. 8: 41-114.

White, K., and D. R. Kankel (1978) Patterns of cell division and cell movement in the formation of the imaginal nervous system in Drosophila melanogaster. Dev. Biol. 65: 296-321.

Yates, R. D. (1961) A study of cell division in chick embryonic ganglia. J. Exp. Zool. 147: 167-182. 